\title{
The Rectum Is for Gravediggers: Homicide, HIV, Homophobia and Identity in Late Twentieth Century France ${ }^{1}$
}

\author{
$\underline{\text { Jack D. Kiely - University College London }}$
}

\begin{abstract}
$\underline{\text { Abstract: }}$
In June 2000, the French Senator Françoise Abadie defined homosexuals as 'les fossoyeurs de l'humanité' ['the gravediggers of humanity']. This definition, which came as the Senator's reaction to the recently enacted PaCS or Civil Partnership legislation, neatly circumscribes the homophobia of the twenty-year period that had preceded it from the beginning of the HIV/AIDS crisis. Concentrating on gay men, this paper focusses on the connections between HIV/AIDSphobia and homophobia in France by focussing firstly in particular on one case of homicide in the late 1980s - that of 'le tueur de vieilles dames' ['the killer of old ladies'], Thierry Paulin, who admitted to at least twenty-one killings, but whose murderous acts were imbricated indissociably by the press not only with his 'identity' as a homosexual, but also with his serological status - thought perhaps to have rendered him disturbed. In this period, HIV infection, homophobia and identity become intertwined with murder, be it in the literal bludgeonings of Paulin, or the fear of gays as spreaders of a deadly disease to the 'innocent' heterosexual population in what ACT Up-Paris call 'le fantasme du séropositif meurtrier' ['the fantasy of the murderous HIV-positive person']. More worryingly, this logic extended to isolationist and even homicidal logic against HIV sufferers around the world, leading Leo Bersani to ask in in 1987 - 'Is the rectum a grave?'

Just over a decade later, the Pacte Civil de Solidarité (PaCS) ['Civil Union'] debates saw similar amalgamations between HIV/AIDS and gay identity, mixed with the homicidal rage of certain of the anti-PaCS demonstrators. This time, however, in transgressing the boundaries of sexual and family norms (in requesting and defending civil partnership rights for the gay 'community'), homosexuals in France had arguably, yet unwittingly and unintentionally, aided in provoking this murderous homophobia in a double bind, and thus to dig their own graves, rather than simply those of the 'rest' of humanity. Therefore, in an extension to Bersani and Abadie's logic, this paper ultimately posits that, in modern homophobic/AIDSphobic society, the rectum is for gravediggers.
\end{abstract}

Keywords:

HIV, AIDS, Homophobia, PaCS, France

DOI:

10.14324/111.2057-2212.072 


\section{Introduction:}

In 1987, at the height of the AIDS crisis, Leo Bersani asked the question 'Is the Rectum a Grave?' This was a reformulation of Simon Watney's statement regarding AIDS that the latter 'offers a new sign for the symbolic machinery of repression, making the rectum a grave' (Watney 1996: 125). When the HIV/AIDS crisis began (before the virus itself was even discovered), it was immediately characterised as the 'gay plague', the 'gay cancer' or the calqued 'cancer gay' in France, and as Watney again describes, gay men were (initially) explained away as the 'cause and source of AIDS' regarding all 'gay men as killers', the only explanation for which is the 'displaced desire to kill them all - the teeming deviant millions oneself' (ibid. 81). In 2000, in the wake of the PaCS debates in France that opened up certain Civil Union rights to gays and lesbians, Senator Françoise Abadie extended his own logic of the grave, defining homosexuals as 'les fossoyeurs de l'humanité' or 'the gravediggers of humanity'.

This paper first proposes that homicide, HIV, homophobia and gay identity in 1980s-1990s France are discursively concomitant, if not inseparable. It does this by focussing primarily on gay men, not because this is of any inherent good nor of any anti-homophobic validity, but because of the pressing need to situate oneself from within the operations of homophobic/AIDSphobic discourse itself - a discourse I take to be principally gay-male centric in this context. Note however that, by gay male, I really mean anal sex, and by anal sex, I really mean the male rectum.

Finally, by highlighting one particular case of transgression of a gay man in France in the 1980s who committed murder himself, and the isolationist, AIDSphobic, homophobic rhetoric of the Front National and then by moving on to the PaCS debates and Senator Abadie's comment, this paper ultimately poses a different reply to Bersani's reformulationquestion. It shows that in a homophobic society, gay men are thought to belong naturally to the categories of the transgressive, HIV-positive, murderous individual or that these flow inexorably from their identity as those who have anal sex. Moreover, as this paper will demonstrate, the ultimate transgression of societal and family norms - the request for equal rights via the PaCS - also starkly highlights the multiple murderous belongings of gay identity for those who fear it. In the inescapable and cruel double-bind of homophobia/AIDSphobia and of 'fossoyeurs', gay men are condemned to dig their own graves and those of humanity itself.

On 17th April 1989, the French press announced the death from AIDS (in prison) of Thierry Paulin, otherwise known as the 'tueur de vieilles dames' ['killer of old ladies']. During Le Journal de $20 \mathrm{~h}$ on $\mathrm{La} \mathrm{5}$, the reporter introduces the bulletin with '[e]n dehors de tout amalgame, au chapitre des faits divers, la mort de Thierry Paulin [...]' ['In other news, and with all amalgam/conflation aside, the death of Thierry Paulin [...]'] ('Thierry Paulin mort du sida', Le Journal de 20h). Paulin, who had been charged with the murders of eighteen "old ladies" in the Paris area and had, in fact, admitted to at least twenty-one killings, is then described in the voiceover report as killing 'comme d'autres vont au bureau' ['as if he was going to the office'] (ibid.) - killings that had created a veritable state of panic in Paris until his arrest. Just(ified) words, with no 'amalgame' ['amalgam/conflation'] one would argue, therefore, for a killer of the aged. But the voiceover then pronounces a phrase that summarises the whole affair: '[...] noceur, mythomane, et homosexuel, il s'affichait sans retenue. Toxicomane, détraqué, peut-être; assassin pour l'argent sans doute. Perturbé par sa maladie, le sida? Pourquoi pas!' ['[...] reveller, perpetual liar, and homosexual, he paraded 
about overtly. Drug-addict, unhinged, perhaps; a killer in it for the money no doubt. Disturbed by his illness, AIDS? Why not!'] (ibid.) With this, Paulin's murderous actions are intertwined not only with his serological status, but with his identity as a gay man, and the latter, doubly, with criminality. Thus, the juxtaposition with 'en dehors de tout amalgame' ['All amalgam/conflation aside'] only serves to reinforce one, and its creation in turn forms a space for homophobia. The virus and its carrier become murderous in what Act Up-Paris described as 'le fantasme du séropositif meurtrier' ['the fantasy of the murderous HIVpositive person'] (Act Up 1994: 174), and so does homosexuality. Paulin becomes the perfect embodiment of a virus that infects homosexuals, but only one that presents a risk to society at large when these homosexuals stray into the heterosexual community. Contrary to what Act Up claim, however, this is no mere 'fantasme' ['fantasy'] - Paulin did murder and did spread panic within a heterosexual community that in many respects mirrors the actions of the virus within the homosexual community of the early 1980s - killing old ladies just as indiscriminately as gay men. As the reporter suggests, his murderous intentions cannot (perhaps or why not!) be separated from that of (his) HIV/AIDS, from homosexuality, from hedonism, drug-use and perpetual lying. For Paulin did not merely murder the innocent, the weak, the defenceless, the then weary Mariannes of the Republic - he led a double life, a homosexual one; frequenting gay clubs at night, and even sections of French high society; funding his habit with his victims' money by day. His lover Jean-Thierry Mathurin even helped him in his crimes ('Thierry Paulin: le tueur de vieilles dames', France 2). Charming, séducteur and debonair, he managed to 'pass' (until his chance arrest) as 'normal'; a nonkiller ('Arrestation meurtriers vieilles dames', France régions 3).

Paulin's ability to 'pass' (as not a murderer) is then analogous to the ability of gays and lesbians to pass as straight in order to avoid homophobia, but also that of an HIV-positive person to 'pass' as HIV-negative in what Catherine Waldby describes as 'Carrier passing' during the asymptomatic stages of HIV infection (1996: 119). Waldby discusses that 'technologies of confession' (120) such as the HIV test in particular reveal not only the truth of serological status, but also of sexual identity de facto (and, I might argue, in Paulin's case the confession of murder). Furthermore, Waldby shows how biomedicine and epidemiology construct a narrative of HIV/AIDS infection through 'risk groups' and the like such that 'in these hierarchies of risk the lower represents a threat to the higher [...]. In the case of the risk categories organised by sex or sexuality, 'targeting' maps itself onto the hierarchy already implied in the binaries of sexual identity, so that women are treated as threats to men, and homosexuals as threats to heterosexuals' (8). Paulin could be seen, therefore, as acting out the phantasm of the risk group - as acting out the threat in slaughtering the old ladies. He is the embodiment of the physical homosexual threat to heterosexual identity in his murderous transgressions. With these risk groups SIDAphobie/AIDSphobia becomes homophobie/homophobia, and vice-versa, and the aforementioned 'amalgame' ['amalgam/conflation'] (without there being one, of course) becomes even more prescient. Nowhere is this more evident than in the discourse of Le Front national; Paulin's bloodthirsty bludgeonings become embroiled in the far-right republican discourse of Jean-Marie Le Pen in his television address of 11 April 1988 before the upcoming Presidential elections, in which he asks: 'Est-ce qu'un pays est sûr quand [...] un tueur a pu pendant trois ans assassiner vingt-et-une vieilles dames?' ['Is a country safe when [...] a killer was able to murder twenty-one old ladies for three years?'], juxtaposed with 'la décadence' ['decadence'] and, of course, in Paulin's case with race (his identity as a Martiniquais) and later (although more indirectly) with 'l'extension fatanstique du SIDA' ['tremendous growth of AIDS'] and 'le laxisme moral' ['moral permissiveness'] ('Jean Marie Le Pen', Campagne électorale, 1988). 
The first response by the FN to the AIDS crisis in France has been dated back to 1986, and was in turn a parliamentary response to the then Health Minister, Michèle Barzach's proposals for a fight against the disease (just prior to the first prevention campaigns) (See Pierre Mathiot 1992: 189-201). These clashes are discussed in the 1988 publication Une société au risque du sida [A Society at Risk of AIDS], penned by Drs. François Bachelot and Pierre Lorane, in which the FN's isolationist policies (sidatoriums) to deal with the AIDS crisis are given in great detail; along with their prescriptions for le dépistage systématique [systematic screening programmes], le contrôle aux frontières [border controls] and their various epidemiological disagreements with the Minister. The work abounds with various warnings regarding the (supposedly underestimated) contagiosity of the virus, and the Drs' advice to combat this, in particular regarding the 'sodomite' and the 'toxicomane' ['drugaddict'] concomitant with their use of the word 'sidaïque' [Le Pen's derogatory neologism for AIDS-sufferers]. Drawing their inspiration from the sanatoria where tuberculosis patients were enhoused at the beginning of the twentieth-century, they argue in favour of a similar policy for AIDS sufferers - sidatoriums - principally for their own treatment, but also for the good of society in general. Jean-Marie Le Pen, the then leader of the Front National had already confirmed these isolationist policies in his now infamous appearance on French television in May 1987, during which he referred to AIDS sufferers as 'sidaïques' and compared them to 'lepers' ('c'est une espèce de lepreux') ('Jean Marie Le Pen', Antenne 2).

As the work progresses, we discover the nature of those 'responsible' for the spread of the virus, as the Drs state that '[...] En France l'épidémie concerne à plus de 90\% des individus appartenant à des 'groupes à risques' bien déterminés: ceux qui pratiquent la sodomie, c'està-dire les relations par voies ano-rectales, les drogués [...] ['In France, the epidemic affects more than $90 \%$ of those individuals belonging to well-defined "risk groups": those who practice sodomy, that is to say, ano-rectal relations [...]'] (Bachelot et al. 1988: 37). They decry the French government's 'cowardice', who, according to them, have preferred to protect the dignity of the gay community at the expense of telling certain 'truths' about the epidemic, finally concluding that '[1]e sida a ruiné les fantasmes sexuels des soixante-huitards attardés' ['AIDS has ruined the fantasies of the latecomers to May 68'] and that '[1]es sodomites distingués ricanaient de l'archaïsme des demeurés qui eux continuaient de faire l'amour par les voies naturelles et qui plus est, avec une seule partenaire: leur femme!' ['Distinguished sodomites sniggered at the archaism of those half-wits who continued to have sex through natural orifices, and what's more, with only one partner: their wife!'] (ibid. 38. My emphasis). In this, AIDS becomes a "punishment" for the (homo)sexual liberation of the 1970s. The homosexual is reduced to the act of sodomy and becomes the 'sodomite' par excellence throughout the rest of the work. It is, thus, this transgression of naturality (in their eyes) that is in part responsible for the HIV/AIDS crisis. Their solution is not to impose stricter laws on homosexuality per se (nor to ban it), but rather to 'arrêter les pratiques de sodomie' ['stop the practices of sodomy'] (ibid. 131).

Moving on, then, to just over a decade later - in 1999, the Socialist government under Lionel Jospin proposed and adopted a new law entitled the Pacte Civil de Solidarité (PaCS) that extended certain civil union rights to gays and lesbians in France. Though the project ultimately achieved its goals, if in a limited sense, and allowed for a greater social integration of homosexuals, it equally (re)ignited onto the public stage the fact that the homosexual identity could potentially pose a threat to the heterosexual family unit through access to civil union/marriage rights (the latter was at least discussed) and the potential to adopt children. It is within this context that we can place Senator Françoise Abadie's comments regarding the PaCS, declaring in the Nouvel Obsévateur in June 2000, '[j]e ne peux pas être favorable à 
ceux que j'appelle les fossoyeurs de l'humanité, ceux qui n'assurent pas l'avenir: les homosexuels' ['I cannot be in favour of those I call the gravediggers of humanity, those who do not ensure its future: homosexuals'] (See Dely 2000). Homosexual identity had, therefore, (re-)become a threat to humanity itself. Abadie also separated the 'normal' heterosexual citizen (those who belong fully to republican society) from the 'abnormal' homosexual (those who presumably do not) when he declared, during the second reading of the PaCS legislation, that, '[1]es citoyens normaux n'ont pas à payer pour les pédés' ['normal citizens shouldn't have to pay for queers'] (See Cuneo 2013). The link of 'destructive power' was also made between the PaCS and the early years of the AIDS crisis when the former was re-baptised 'Pratique de contamination sidaïque' [roughly 'AIDS contamination practice' (using the same rhetoric as that of the Front national] by the Senator Emmanuel Hamel (qtd. in 'Observatoire du Pacs' 2001) thus not only reinforcing the homophobic link between AIDS and homosexuals, but the infectious annihilatory ends of the latter, such that PaCS $=$ SIDA/AIDS in this equation of belonging to both groups.

In addition to this, the discursive slippages of certain protestors of the PaCS descended into outright homophobia, some of which remains inscribed on the French psyche to this day 'les pédés au bûcher' ['queers to the stake'] (from the 31 January 1999 protest) seemingly having become the 'gold standard' of homophobic discourse against which all else is measured. This "bouffée d'homophobie" ['surge of homophobia'], as the newspaper Libération described it, was reportedly in reaction to the raising of an Act Up-Paris banner at the Trocadéro entitled 'homophobes', signed 'les folles de Chaillot' ['queens of Chaillot'] (See Forcari and Grosjean 1998). Thus, this self-fulfilling prophecy transforms the members of Act Up (and 'les pédés' ['queers'] in general) as the gravediggers of humanity (the threat to heterosexuality) into their own unwitting and unwilling morticians; their fate sealed through immolation instead of the burial promised to the rest, in this modern witch-hunt of the sodomite - a temporal schism to a past when the latter were indeed burnt at the stake. Accompanying this murderous logic could be heard 'Sales pédés, brûlez en enfer! Arrêtez de nous faire chier avez votre sida!' ['Dirty queers, burn in hell! Stop pissing us off with your AIDS" NB. 'Chier' literally translates as 'to shit'] (qtd. in Borrillo and Lascoumes 2002: 93). The endless association between homosexuality and AIDS that brings us back to the first years of the crisis, and also the annihilation by hell-fire that links us back to the stake.

\section{The rectum is for gravediggers}

To conclude, therefore, once more with Simon Watney's statement regarding AIDS that the latter 'offers a new sign for the symbolic machinery of repression, making the rectum a grave' (Watney 1996: 125). But is it? Bersani discusses how AIDS has legitimised the 'impulse to murder [gay men]' (1987: 198) as purveyors of disease through their voracious and uncontrollable sexual appetite; an appetite indistinguishable from anal sex - just as I would argue Paulin's murderous intent was indistinguishable from his debonair wit, or his homosexual 'charm', and indeed his 'madness from AIDS' in the opening voiceover 'amalgam'.

However, the proposal of the PaCS in France to extend cohabitation rights to gays and lesbians and the now familiar comment of Françoise Abadie from the debates transforms (or rather re-extends the transgressive potential of) homosexuals (read - gay men) from the endgame of civilisation as the purveyors of disease through their promiscuous sexual activity to those who do not ensure humanity's future through its reproduction. Grave becomes, thus, gravediggers. And the digging is done by the (gay) man on top. Anal sex is the annihilatory 
act that can not only potentially infect one's partner (with HIV), but Abadie's diatribe in the wake of the PaCS reminds us of its power to discontinue civilisation through the wasted libidinal energy whose future is in the rectum rather than where it is supposed to be. Thus, the rectum becomes the site where gay men actively dig for the obliteration of humanity. In this the traditional active-passive distinction (and rejection) is turned on its head. The passive, the fucked, the bottom-boy has never belonged to the category of the singularly pathological, the truly homosexual and a threat, but the insertor, the active, the top is he who fucks (digs) to end civilisation.

Moreover, in a double-bind, those who choose to down tools (even if temporarily) for a "higher" purpose of securing gay rights (such as those proposed by the PaCS law) are faced with the reaction of a homophobic society that reflects the discourse back on them to the rectum and back to AIDS. Act Up-Paris's self-evident 'Homophobes' that was met by 'Sales pédés, brûlez en enfer! Arrêtez de nous faire chier avec votre sida!' ['Dirty queers, burn in hell! Stop pissing us off with your AIDS'] not only brings us back to AIDS, as I have argued, but to the shit of the rectum in 'chier'. And 'votre SIDA' ['your AIDS'] offers us a sense of possession, and indeed a site of belonging, that is all too familiar with gay men as being the 'cause and source of AIDS' or, as Bersani puts it, makes mean that 'homosexuals are killers' (1987: p. 211). Once more, gay men are murderers as the source of HIV and invited to be the objects of murder themselves or to 'burn in hell' as 'dirty queers'. Furthermore, Bersani's extension of Watney's point of comparison between gay men and the disease spreading (women) prostitutes of the $19^{\text {th }}$ century as 'contaminated vessels, conveyancing 'female' venereal diseases to 'innocent' men' (Bersani 1987: 211; Watney 1996: 34) holds true in the case of the PaCS. Another placard 'pas de neveux pour les tantouses' ['no nephews for faggots' - Tantouse is a deformation of the word 'tante' (also often used as a homophobic slur itself) meaning 'aunt'] that could be seen during the anti-PaCS demonstrations makes the direct link between (in this case) male homosexuality through the anti-gay (male) insult and female sexuality; linking gay men to infection just as the prostitutes from the $19^{\text {th }}$ century '[...] spreading their legs with an unquenchable appetite for destruction [...] unable to refuse the suicidal ecstasy of being a woman' (Bersani 1987: 211-212). The suicidal ecstasy in this case becomes not only 'spreading one's legs', but the unconscious appetite for destruction in being the 'top' through the provocation of the homophobe. In requesting equal rights and transgressing the boundaries of sexual and family norms, gay men (and women) are unwillingly digging their own graves as these demands allow in turn for the sublimation of homophobic fears and violence. If 'les pédés au bûcher' ['queers to the stake'] could be heard on the Parisian streets in November 1999 it is, at least in part, because gays themselves have come out of the woodwork (moving away from just sex to monogamous heteronormalising desires), and are then painfully invited to return to it in a different form - the stake. If Bersani can state in 1987 that '[...] there is no political need to save or protect any homosexuals at all' then this is certainly not the case now, and it is this new 'need' that in turn provokes a certain homophobia in a society that has not yet divested itself of it. In the case of the PaCS in France, this provocation then led back to the discourse of AIDS as the oppression of gay men as what Bersani calls a 'moral imperative' (204). We are, thus, condemned to be passive -which is synonymous with suicide and the grave (not only in sex, but as per Act Up's raising of the banner, and daring to request equal rights) - and actively murderous (of humanity) at the same time as we fuck or dig to ensure its destruction. And, as we have seen with Paulin, homosexual identity and AIDS in France became indissociable with actual murder - the literal homophobic embodiment of the gay man's desire to kill, reflecting back the fear of active homosexuality. Amongst homophobic, AIDSphobic, homi/homocidal 
society such as in France, therefore, for gay men - the rectum is not (nor has ever been) only a grave, but is for gravediggers.

In this way, there is perhaps the possibility for a "reclaiming" of homophobia, not only because of its power to galvanise opinion and advance the cause, but because in some of its endless associations, in a 'véritable explosion discursive' ['veritable discursive explosion'] (Foucault 1976: 25), it inadvertently promotes what it seeks to avoid - gay sex. Transgressing the boundaries of the rectum also offers us perhaps a sense of belonging. This, because of the dizzying power afforded to us that the 'top' might just be able to fuck (dig) to end it all.

\section{Works Cited :}

'Arrestation meurtriers vieilles dames.' Soir 3. France Régions 3. 02 December. 1987. Television. Web. 09 September 2015.

<http://www.ina.fr/video/CAC02003979/arrestation\%ADmeurtriers\%ADvieilles\%ADdames $\%$ ADvideo.html $>$.

'Jean Marie (sic) Le Pen.' L'Heure de vérité. Antenne 2. 06 May. 1987. Web 14 July 2015. <http://www.ina.fr/video/CAB87017521>.

'Jean Marie LE PEN.' Campagne électorale: élection présidentielle $1^{\text {er }}$ tour. Commiss. Nat. De la Communication. Et des Libertés. 11 April 1998. Web. 09 September. 2015. <http://www.ina.fr/video/CAB88014338/jean\%ADmarie\%ADle\%ADpen\%ADvideo.html>.

'Thierry Paulin mort du sida.' Le journal de 20h. La 5. 17 April. 1989. Television.

Web. 09 September. 2015. <https://www.ina.fr/video/CAG05071560/thierry-paulin-mort-dusida-video.html $>$.

'Thierry Paulin: le tueur de vieilles dames.' Faites entrer l'accusé. France 2. June. 2004. Television.

Act Up-Paris. Le Sida: combien de divisions? Paris: Éditions Dagorno, 1994. Print

Bachelot, Dr. François and Lorane, Dr. Pierre. Une société au risque du SIDA. Paris: Éditions Albatros, 1988. Print.

Bersani, Leo. 'Is the Rectum a Grave.' AIDS: Cultural Analysis/Cultural Activism 43.Winter 1987. 197-222.

Borrillo, Daniel and Lascoumes, Pierre. Amours égales? Le Pacs, les homosexuels et la gauche. Paris: Éditions La Découverte, 2002. Print.

Cuneo, Louise. 'Christine Boutin: 'Le débat sur le Pacs a décrispé le tabou de l'homosexualité en France'.' Le Point. 13 October 2013. Web. 06 August 2015.

$<$ http://www.lepoint.fr/actualites-societe/2009-10-13/christine-boutin-le-debat-sur-le-pacs-adecrispe-le-tabou-de-1/920/0/385260>.

Dely, Renaud. 'Le PRG exclut son sénateur homophobe.' Libération. 01 August. 2000. Web. 05 August 2015.

$<$ http://www.liberation.fr/politiques/2000/08/01/le\%ADprg\%ADexclut\%ADson\%ADsenateu r\%ADhomophobe_333102>.

Forcari, Christophe and Grosjean, Blandine. 'Les anti-Pacs défilent en famille très catholique.' Libération. 01 February 1998. Web. 09 September 2015.

<http://www.liberation.fr/evenement/1999/02/01/les-anti-pacs-defilent-en-famille-trescatholique_263800>.

Foucault, Michel. Histoire de la sexualité I: La volonté de savoir. Paris: Editions Gallimard, 1976. Print. 
Mathiot, Pierre. 'Le sida dans la stratégie et la rhétorique du Front national', in Sida et politique: les premiers affrontements (1981-1987), ed. Pierre Favre. Paris: Éditions

L'Harmattan, 1992. 189-201. Print.

Obsérvatoire du PaCS. 'Pacs: qu'en disent vos députés?' 2001. Web. 5 August 2015. $<$ http://obspacs.chez.com/deputes.htm>.

Waldby, Catherine. AIDS and the Body Politic: Biomedicine and sexual difference. New York: Routledge, 1996. Print.

Watney, Simon. Policing Desire: Pornography, AIDS, and the Media. Minneapolis: University of Minnesota Press, 1996. Print.

\section{Biography:}

Jack Kiely is a PhD student in French at University College London. He previously obtained an MA in Language, Culture and History: French and Francophone Studies at UCL, and a BA (Hons) in French at the University of Sussex. His main research interests include: LGBT history in France, gender studies and queer theory.

(C) 2017, The Author(s). This is an Open Access article distributed under the terms of the Creative Commons Attribution License (CC-BY) 4.0 https://creativecommons.org/licenses/by/4.0/ which permits unrestricted use, distribution, and reproduction in any medium, provided the original author and source are credited.

\section{Endnote:}

${ }^{1}$ N.B. All translations are my own. 